\section{Wisconsin Wild: Another Petaloid Male-sterile Cytoplasm for Carrot}

\author{
T.E. Morelock ${ }^{1}$ \\ Department of Horticulture and Forestry, University of Arkansas, Fayetteville, \\ AR 72701
}

\author{
P.W. Simon ${ }^{2}$ and C.E. Peterson ${ }^{3}$ \\ Vegetable Crops Research Unit, Agricultural Research Service, U.S. \\ Department of Agriculture, Department of Horticulture, University of \\ Wisconsin, Madison, WI 53706
}

Additional index words. Daucus carota L., vegetable breeding

Cytoplasmic diversity is a desirable attribute in the production of $F_{1}$ hybrids. Even though most breeders agree with this concept, the vast majority of carrot (Daucus carota L.) hybrids produced in the United States are in one cytoplasm, i.e., the Cornell cytoplasm. To expand the diversity of cytoplasm for cultivated carrot, the U.S. Dept. of Agriculture announces the release of the Wisconsin Wild cytoplasm.

\section{Origin}

Wisconsin cytoplasm was derived from a small population of petaloid male-sterile wild carrots found growing near Madison, Wis., in Summer 1970. This population of wild carrots was examined because of the unusual pale pink of the umbels. Closer examination of individual flowers revealed that they were petaloid male-sterile and were phenotypically very similar to petaloid male-sterile flowers produced by the Cornell cytoplasm (Peterson and Simon, 1986; Struckmeyer and Simon, 1986).

Four sterile plants were recovered by digging and keeping the rootball intact. Individual plants were then transplanted into 1.7$\mathrm{L}$ pots and placed in an air-conditioned greenhouse. The single most vigorous survivor of transplanting was then caged with a bouquet of flowers from the inbred MSU 5931M, a maintainer of sterility in the Cornell cytoplasm. The pollen source was kept in water and periodically replaced to ensure an adequate, continuous supply.

The $F_{1}$ seed were sown in muck soil at Palmyra, Wis., and in mineral soil at Madison, Wis. The $\mathrm{F}_{1}$ roots, easily identified by their whiteness and exceptional vigor, were planted

Received for publication 29 Aug. 1995. Accepted for publication 14 Apr. 1996. The cost of publishing this paper was defrayed in part by the payment of page charges. Under postal regulations, this paper therefore must be hereby marked advertisement solely to indicate this fact.

${ }^{1}$ Professor.

${ }^{2}$ Research Geneticist and Professor.

${ }^{3}$ Research Horticulturist and Professor (deceased). crosses were made to MSU 5931M and outcrosses to MSU 9541M, MSU 2710M, and MSU $10374 \mathrm{M}$, all inbred maintainers of petaloid sterility in the Cornell cytoplasm. Progenies of these crosses were grown at Palmyra in 1972 and the vernalized roots were planted in the greenhouse in November. Populations of all crosses were classified for sterility and were backcrossed to the appropriate recurrent parent.

All of the $43 F_{1}$ plants from the cross, Wisconsin Wild x MSU 5931, were petaloid with no anther-like structures. Seventy-five $\mathrm{BC}_{1}$ plants to MSU 5931M, grown in the greenhouse in Winter 1972, were petaloid (Table 1) and male-sterile. Petal color was green.

Progenies from crosses to other petaloid maintainers (Wisconsin Wild $\times 5931 \mathrm{M}$ ) $\mathrm{F}_{1} \times$ 2710M, (Wisconsin Wild $\times 5931 \mathrm{M}$ ) $\mathrm{F}_{1} \times$ $9541 \mathrm{M}$, and (Wisconsin Wild $\times 5931 \mathrm{M}) \mathrm{F}_{1} \times$ $10374 \mathrm{M}$ were all completely petaloid. These three crosses could be considered $\mathrm{BC}_{1}$ progeny with respect to sterility maintenance, since they are all maintainers for the Cornell petaloid sterility. The combined $\mathrm{BC}_{1}$ population of 270 plants (Table 1) were all petaloid steriles, providing good evidence that petaloid sterility is maintained in the Wisconsin Wild cytoplasm by the same genotypes that maintain petaloidy in the Cornell cytoplasm. More recent crosses with 11 other carrot inbreds known to maintain Cornell petaloid male sterility yielded 1439 sterile progeny and no fertiles to further indicate that sterility is maintained in the Wisconsin Wild and Cornell cytoplasm by the same nuclear genes.

The cross to the $670 \mathrm{C}$ line, a known restorer of fertility in Cornell cytoplasms, produced nine male-sterile plants and one malefertile plant. Crosses with 14 individual plants in the greenhouse after cold induction. Back- of $3187 \mathrm{C}$ and 21 individual plants of HCM (two other known restorers of fertility in Cornell cytoplasm) yielded $0 \%$ to $35 \%$ fertile plants in populations of $<30$ progeny from each individual plant. As two or more genes condition restoration of fertility in carrot (Thompson, 1961), these populations are too small to conclude that the same genes restore fertility in Wisconsin Wild and Cornell cytoplasms, but the range in incidence of fertility among populations in either cytoplasm suggests that the Wisconsin Wild cytoplasm is similar or identical to the Cornell source with regard to restoration of fertility.

\section{Description}

The individual florets produced by the Wisconsin Wild cytoplasm appear phenotypically identical to those produced by the Cornell cytoplasm. Individual florets have anthers replaced by petal-like structures that produce no pollen, thereby producing $100 \%$ male sterility in the primary and higher-order umbels (Fig. 1). The sterility appears to be maintained or restored by the same maintainer or restorers as the Cornell cytoplasm.

Root, leaf, and floral appearance are similar in Wisconsin Wild and Cornell petaloid male-sterile plants. The only exception to this similarity was noted for two inbreds (B7241 and B8532) with white or cream-colored petals; Wisconsin petaloids tended to be more distinctly white, whereas Cornell petaloids had more of a pale-green appearance in a comparison of 60 to 100 plants of each inbred. Petal color is apparently under nuclear control, but otherwise not characterized genetically so the differences noted may not reflect a cytoplasmic effect, but rather sampling error.

A preliminary comparison of mitochondrial genome restriction enzyme patterns indicates some differences between the Wisconsin Wild and Cornell petaloid cytoplasms; however, differences also occur within each of these cytoplasms, as has also been noted within male-fertile populations (Ichikawa et al., 1989; Pingitore et al., 1989; Simon, unpublished; Steinborn et al., 1992). Further phenotypic and molecular comparison is necessary to determine the extent of similarity of the Wisconsin Wild and Cornell petaloid male-sterile cytoplasms.

\section{Availability}

Inquiry regarding seed availability for the Wisconsin cytoplasm should be directed to P.W.S.

Table 1. Maintenance of Wisconsin petaloid by Cornell maintainers.

\begin{tabular}{lccc}
\hline & & \multicolumn{2}{c}{ Male } \\
\cline { 2 - 4 } Pedigree & Generation & Sterile & Fertile \\
\hline Wisconsin Wild x 5931M & $\mathrm{F}_{1}$ & 43 & 0 \\
(Wisconsin Wild x 5931M)F & 75 & 0 \\
(Wisconsin Wild x 5931M)F $F_{1} \times 2710 \mathrm{M}$ & $\mathrm{BC}_{1}$ & 56 & 0 \\
(Wisconsin Wild x 5931M)F & $\mathrm{F}_{1}$ & 75 & 0 \\
(Wisconsin Wild x 5931M)F & $\mathrm{F}_{1}$ & 64 & 0 \\
Summation of progenies & $\mathrm{F}_{1}$ & 270 & 0 \\
\hline
\end{tabular}




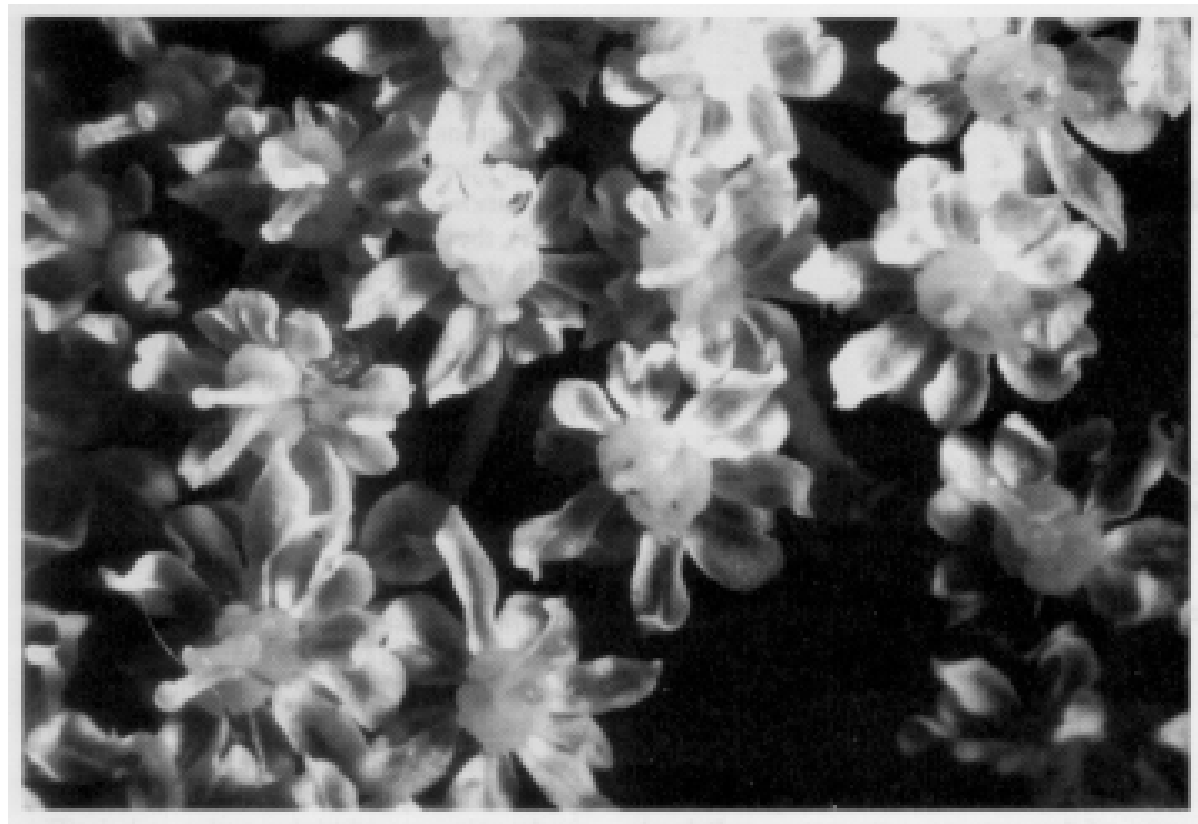

Fig. 1. Wisconsin Wild petaloid male-sterile carrot flowers.

\section{Literature Cited}

Ichikawa, H., L. Tanno-Suenaga, and J. Imamura. 1989. Mitochondrial genome diversity among cultivars of Daucus carota (ssp. sativus) and their wild relatives. Theor. Appl. Genet. 77:3943.

Peterson, C.E. and P.W. Simon. 1986. Carrot breeding. In: M.J. Basset (ed.). Breeding vegetable crops. AVI Publishing Co., Westport, Conn.

Pingitore, M., B. Matthews, and P.J. Bottino. 1989. Analysis of the mitochondrial genome of Daucus carota with male sterile and male fertile cytoplasm. J. Hered. 80:143-145.

Steinborn, R., A. Weihe, and T. Boerner. 1992. Mitochondrial genome diversity within a cultivar of Daucus carota (ssp. sativus) revealed by restriction fragment analysis of single plants. Plant Breeding 109:75-77.

Struckmeyer, B.E. and P.W. Simon. 1986. Anatomy of fertile and male-sterile carrot flowers from different genetic sources. J. Amer. Soc. Hort. Sci. 111:965-968.

Thompson, D.S. 1961. Studies on the inheritance of male-sterility in carrot, Daucus carota L. var. sativa. Proc. Amer. Soc. Hort. Sci. 78:332-338. 